\title{
Slavomira Ribarova
}

\section{KOLIKO SU SVETI "SVETI“ U FRAZEOLOGIJI}

\section{Uvod}

Dredmet naše analize su onomastički supstantivni i poredbeni frazemi s pridjevom sveti u kombinaciji s vlastitim imenom kao sastavnicom. Frazemi su ekscerpirani iz frazeoloških rječnika češkoga (SČFI) i hrvatskoga jezika (HSRPF, FRHSJ, HFR). Pri promatranju frekvencije i danih kolokacija pouzdali smo se u Český národni korpus ČNK (ČNK2000, ČNK2005, ČNK2006) i Hrvatski nacionalni korpus (HNK). ${ }^{2}$

Kvalitativni pridjev sveti je sveslavenska riječ s izvornim pretkršćanskim (poganskim) značenjem „moćan, snažan“; novije kršćansko značenje je današnji „sveti“ (ČES, 617). S obzirom na to da se radi o kvalitativnom semantičkom kvalifikacijskom pridjevu, ne iznenađuje činjenica da on u češkom jeziku ima visoku frekvenciju (svatý u SYN2006, SYN2005, SYN2000 ima 81798 pojavnica), a i u hrvatskom jeziku (sveti u HNK ima 3010 pojavnica $)^{3}$. Kolokacije uz pridjev sveti u oba jezika najčešće su blisko povezane s kršćanstvom i pozitivno vrednuju imenicu koja slijedi. Na taj se način pozitivno određuju vlastite imenice muškoga (češ. Vit, Vavřinec; hrv. Blaž, Vlah) i ženskoga roda (čes. Kateřina, Barbora; hrv. Ana, Lucija), kao i opće imenice (čes. mše, křiž, grál; hrv. misa, križ, gral).

Pogledamo li supstantivne frazeme s vlastitim imenom kao sastavnicom, u oba jezika pronalazimo sličnu situaciju, npr. češ. Svatý otec, Písmo svaté, svatý pokoj, svatá/svatosvatá pravda; hrv. Sveti otac, Sveto pismo, sveta dužnost, sveta istina itd. Ova nas usporedba navodi na zaključak da se kvalitativni pridjev sveti ne desemantizira, da uvijek pozitivno vrednuje imenicu koja slijedi i da se njegova semantika izravno vezuje uz kršćanstvo.

Cilj ovoga rada je odgovoriti na pitanje je li to tako i u slučaju kada se radi o antroponimskim frazemima s vlastitom imenicom kao sastavnicom, te istovremeno otkriti koliko su ovi frazemi motivirani konkretnim ili fiktivnim denotatima.

Cjelokupni zbroj vlastitih imenica u češkim (120) i u hrvatskim (62) frazeološkim rječnicima pokazuje da je većina njih muškoga roda, a pojavljuju se u supstantivnim i poredbenim frazemima, kako u češkim ( $81 \%$, od kojih se $3,3 \%$ vežu sa pridjevom svatý), tako i u hrvatskim ( $73 \%$ od kojih se 2 vežu s pridjevom sveti). Ženska vlastita imena imaju manje pojavnica u češkom (19\%, od kojih se jedna veže s pridjevom sveta) nego u hrvatskom (u kojemu se od $27 \%$ imena ni jedno ne veže s pridjevom $\left.s v e t a^{4}\right)$.

1 Tekst je hrvatska verzija članka (na češkom) pod naslovom Nakolik jsou svatí „svatí“ ve frazeologii, objavljena u zborniku Stowo. Tekst. Czas - IX-Człowiek w przestrzeni słownika i tekstu, Szczecin 2008.

2 U slučaju kad se frazem nije pojavio u korpusu, pojavnice smo tražili na internetskom pretraživaču Google (G.).

3 Izrazito niža frekvencija u hrvatskom je uzrokovana veličinom samih korpusa (ČNK: 500 mil. a HNK: 101,3 mil. slov) i zato frekvenciju promatramo u usporedbi sa veličinom HNK a ne uspoređujemo s ČNK.

$4 \quad$ Fink (usp. PF) u kazalu navodi dijalektalno ograničeni frazem: kao sveta Bona, koji ne uvrštavamo u analizu, jer nije zabilježen u HFR i nismo našli niti jednu zabilježenu potvrdu upotrebe toga frazema (u HNK i G.). 
Najčešći motivacijski izvor za uporabu vlastitih imena u frazemima je Biblija (Abraham, Eva itd.) i antička mitologija (Damokles, Venuše; Damoklo, Venera itd.); osim toga postoji cijeli niz vlastith imenica koje se vežu s kulturno-povijesnim realijama (s legendama, mitovima, pričama i književnošću). Pojava vlastitoga imena u frazemima uvijek je znakovita, jer vlastita imenica obično gubi svoju bit koja je svojstvena njenom denotatu (ČL, 182 ).

Iz perspektive motivacijskoga taloga u materijalu su zastupljene dvije suprotne skupine: u jednoj se vlastita imena kao sastavnice motivacijski odnose na postojeći događaj iz života sveca, dok se u drugoj pojavljuje fiktivni svetac. Objema skupinama je zajednička desemantizacija sastavnice sveti i slabljenje prvotnog značenja vlastite imenice. Njihova semantika u najmanju ruku donosi kolokvijalan ton i u većini slučajeva i dašak humora s mogućim pratećim nijansama. Humor može prenijeti govornikovo pozitivno ili negativno vrednovanje, a može biti i znak govornikovog opuštanja nakon osobnog lošeg iskustva te može pokazivati govornikov osjećaj nadmoći ili podsmijeha (VTTH, 201).

\section{Analiza}

2.1. U prvoj grupi se pojavljuju frazemi u kojima vlastita imenica ima konkretni denotat: u češkom Svatý Vít i Svatý Jan, u hrvatskom Sveti Petar. Njihova denotativna jezgra povezana je s konkretnom slikom koja je izvor konotacija. Iako je motivacijski izvor logičan i može se potvrditi, vlastita imenica u kolokaciji s pridjevom gubi svoju individualnu osnovu (svoju bit).

Prema podatcima u ČNK jedna od najčešćih kolokacija pridjeva sveti je vlastita imenica Vit, što ne iznenađuje s obzirom na veliko štovanje sicilijanskoga mučenika - svetoga Víta u Češkoj: on je zaštitnik cijelog niza zemalja i gradova, između ostaloga je i zaštitnik Češke, Praga i Saske. ${ }^{5}$ Sveti Vit je osim toga poštovan i kao zaštitnik oboljelih od epilepsije, pa se grčeviti pokreti povezani s ovim poremećajem centralnoga živčanog sustava kolokvijalno označavaju supstantivnim frazemom: tanec svatého Vita. ${ }^{6}$ Uporaba ovoga frazema kao kolokvijalnoga sinonima za epilepsiju uvrštava ovaj izraz terminološkoga karaktera u područje frazeologije u širem smislu:

Npr. Těžkou artrózu v obou kolenech a takzvaný < tanec svatého Vita $>$. Vždycky,když se roztanči, tak prý řve SYN2006PUB.

U usporedbi s ostalim frazemima ovaj ima najviše pojavnica (s frekvencijom 11) kod kojih je očigledno da se frazem ne koristi samo za kolokvijalno označavanje epileptičkoga napada, nego i za opis bilo kakvih beznačajnih grčevitih pokreta koji mu nalikuju:

Npr. pozorovali předtančení. Potom páru zatleskali a začal $<$ tanec svatého Vita $>$. V rychlém sledu se střídaly všechny klasické SYN2005.

Frazem se pojavljuje i s novom, u rječniku nezabilježenom paradigmatskom supstitucijskom općečeškom varijantom svatýho, što ukazuje na njegovu uporabu u govornom jeziku:

Npr. Ještě šest neděl s váma a celý kasárna dostanou $<$ tanec svatýho Víta $>$. Právě ten večer mě Calendar tak nevděčně SYN2005.

$5 \quad$ Sv. Víd jedan je od najpopularnijh svetaca u svijetu i crkvi. Već u 14. stoljeću bio je jedan od 14 svetih pomoćnika u nuždi, tako da se njemu ljudi mole za različite stvari.

6 Prema SČFI II frazem postoji i u A St. Vitus' dance $\mathbf{N}$ Veitstanze $\mathbf{F}$ danse de Saint Guy $\mathbf{R}$ пляска святого Витта. 
Sveti Ivan (Svatý Jan) se može odnositi na nekoliko svetaca (npr. Ivan Krstitelj, Ivan Nepomuk, Ivan Evanđelist itd.) ili naselja (npr. Svatý Jan - županija Př́ibram, Svatý Jan nad Malší, Svatý Jan pod Skalou itd.). Njegova pojava u frazemima najvjerojatnije je povezana s imenom sv. Ivana Nepomuka, zaštitnika Češke i Bavarske, štovanoga kao mučenika tajne ispovijedi i kao zaštitnika vode. Njegov je kult neizmjerno proširen i neodvojivo povezan s češkim barokom, kada je bio jedan od najznačajnijih svetaca. Njegov prikaz u tipično ukočenoj baroknoj formi može se pronaći uglavnom na mostovima. Poredbeni frazem stát někde jako svatý (Jan) na mostě (s frekvencijom 3) neblagonaklono opisuje osobu, najčešće muškarca, koja negdje stoji besposleno (pasivno), bez pokreta, glupo i neodlučno. ${ }^{7}$

Npr. nepozorovaně se ztratil. Ale Švejk tam dosud stál jako < svatý na mostě >, což nebylo nic divného uprostřed kamenných SYN2005.

Most je ovdje jasno povezan s Kamenim (Karlovim) mostom, s kojeg je Ivan Nepomuk bio bačen u Vltavu 20. 3. 1393. godine. Kip je na ovom mjestu bio postavljen 1963. godine. Ima veliki broj kopija i zahvaljujući njima je Ivan Nepomuk na mostu postao iznimno poznat svetac. Kipovi općenito, posebno svetoivanjski, spadaju među tipične atribute tradicionalnoga češkoga krajolika. Zato ne iznenađuje da je u ČNK potvrđeno ispuštanje sintagmatske varijante vlastite imenice Ivan $(\mathrm{Jan})^{8}$. Kipovi se u velikom broju nalaze ne samo kod mostova, već i na poljima i drugim mjestima, što je u danom frazemu motivacijski izvor rjeđe korištene paradigmatske varijante za dědinou (s frekvencijom 1):

Npr. objímající mohutné ženské poprsí. Byl zamlklý < jak svatý za dědinou > a do krve si rozškrabával bradavice: SYN2000.

U hrvatskim je frazemima ${ }^{9}$ sveti Petar, svetac kojeg je Isus izabrao da postane prvi od dvanaest apostola, motivacijski izvor poredbenog frazema: košta što kao svetog Petra kajgana (s frekvencijom 1), u kojem nikakva realna motivacija nije očita. Tek poznavanje apokrifnog događaja o Isusu i svetom Petru može nam ponuditi neka objašnjenja. Naime, navodno je pri posjetu škrtom seljaku koji im nije ponudio hranu sv. Petar otišao u kuhinju da bi napravio kajganu. Kako je to seljak primijetio, krenuo je da ga istuče štapom. Misleći da će ga nadmudriti, sv. Petar je zamijenio mjesto s Isusom, ali gospodar je odlučio da će ih obojicu jednako kazniti, tako da je Petra istukao dvaput. Otuda proizlazi značenje ovoga frazema „skupo za nešto platiti“ i ustaljena uporaba glagola koštati ili njegovog sinonima:

Npr. priznati da ta fikcija stoji Hrvate kao < svetog Petra kajgana >. Nacionalov istraživački tim proveo je HNK_v20.

Pri upotrebi govornik rijetko kada ima u svojoj svijesti ili podsvijesti činjenice o motivaciji danog frazema. Stvaranje konkretne slike proizlazi iz uključivanja konkretnih jedinica bez motivacijskog konteksta, a semantička konotacija dolazi do izražaja na osnovi

U hrvatskom se jeziku pojavljuje poredbeni frazem s identičnim značenjem ali bez pridjevske sastavnice sveti: stajati kao drveni (lipov) svetac, čiji je motivacijski talog prikaz sveca u obliku drvene figure.

$8 \quad$ Može se uzeti u obzir i mogućnost da se radi o dodavanju, a ne izostavljanju sintagmatske varijante Jan u frazemu stát j. svatý na mostě/za dědinou. Npr. Zaorálek (ZLČ, 376, 589, 590) navodi ovaj frazem bez komponente Jan, iako kao dijalektalno ograničen. Odgovor na ovo pitanje može dati samo detaljnija dijakronijska analiza upotrebe ovog frazema, što nije predmet naše analize.

9 Dijalektalno ograničen i u rječnicima nepotvrđen još je frazem gledati u koga kao u svetog Antu, u kojemu je vlastito ime iskorišteno kao varijanta komponente $B$ og. 
prenesenoga značenja, jer govornik shvaća desnu stranu izraza (comparatum) kao prototip. [SČFI, 476]. U frazemima stát někde jako svatý (Jan) na mostě i košta što kao svetog Petra kajgana potencira se ustaljena komponenta lijeve strane frazema. Nepoznavanje motivacije ostavlja prostor za uključivanje humoristične sastavnice pri evaluaciji dane situacije.

Svaki od frazema konceptualno izražava stav prema drugom čovjeku i istovremeno opisuje ili način njegova kretanja (sv. Vit), ili negaciju kretanja (sv. Jan) ili donosi negativno vrednovanje čega (sv. Jan, sv. Petar).

2.2. Osim gore navedene skupine bogatiji repertoar vlastitih imenica pružaju igre riječima, u kojima frazeologija raspolaže svojim vlastitim imenima - fiktivnim i stvaranim po analogiji s pravima (ČL, 182).

U odnosu na frazeme prve skupine ovdje je snažnije izražena sastavnica vrednovanja s obzirom na određenu situaciju koja se procjenjuje negativno. Uporaba pridjeva sveti i spajanje s fiktivnim vlastitim imenom unosi veliku ekspresivnost u neblagonaklono šaljivu, čak i podrugljivu komponentu. Kod fiktivnih vlastitih imena pojavljuju se tri mogućnosti njihovog nastajanja. ${ }^{10}$

2. 2.1. Fiktivno se ime može tvoriti od ekspresivne imenice, kao što je to u češkom jeziku na primjer utřinos - „,balavac“, ,šmrkavac“ ili „dosta mlad, neiskusan čovjek“, koje u supstantivnom frazemu svatý Utřinos (s frekvencijom 3) u kolokaciji s naizgled pozitivnim pridjevom sveti devalorizira i potencira opis nezrelog i ,neiskusnog ili glupog, neodlučnog i sl. čovjeka“".

Npr. Kdo se tak dobře trefil, nevíme: Asi < svatý Utřinos >. Ty tady s tou svíčkou stojís jak klekánice SYN2000.

Njegova poredbena varijanta: stát (někde) /koukatj. svatý/svatej Utřinos ${ }^{11}$ odnosi se na određenu djelatnost i negativno kategorizira pasivnost i mentalnu nesposobnost pojedinca:

Npr. pravil, že se Pajda nezdá, že kouká jako < svatý Utřinos >, když se mu nadává, ale je to děsný previt SYN2005.

Pomoću paradigmatske glagolske varijante s být zabilježen u ČNK frazem koji se u širem kontekstu općenito odnosi na negativno vrednovane stavove i osobine:

Npr. mně hoši budou nadávat, že jsem jako ten $<$ svatý Utřinos $>$. Nevynechám housle ani jednou, s nikým SYN2005.

2.2.2. Drugi izvor stvaranja fiktivnoga vlastitoga imena je nastojanje da se postigne ritmička harmonija i pomoću bliskih jedinica stvori rima. Imena ovoga tipa pojavljuju se u oba jezika. Nepostojeći svetac Dyndy u češkom je povezan s rimom: anebo nikdy koja dodaje značenju veliku prepoznatljivost. Supstantivni frazem na svatého Dyndy (s frekvencijom 5) izražava nevjericu govornika u mogućnost da se što ostvari:

$\overline{10}$ U tekstu se osvrćemo samo na frazeme zabilježene u SČFI. Veći broj frazema ovog tipa navodi L. Stěpanova (usp. SČRF): na svatého Ajaj; na svatého Až; na svatého Brala; na svatého Bůhví; na svatého Jindy; na svatého Nerobiša; na svatého Nikdýše; na svatého Nikdáše; na svatého Nikdy; na svatého Vida; mit svatého Berouse; je svatého Honoráriusa; dělat na svatého Moha něco; udèlat až na svatého Kováre něco; je svatého Lenocha; dostat na chrám páně svatého Bouchala, kouká jak svatý Mrkal bez klapek, koje navodi i Zaorálek (ZLČ 23, 590).

11 L. Stěpanova (usp. SČRF), navodi još varijantu: stoji jak svatý Utřinos na hrázi. 
Npr. řě̌ení do roušky mlčení s vědomím, že se tak stane až < na svatého Dyndy >. Pokud jde o majetkové požadavky sudetských Němců SYN2006PUB.

trefně popsané panem Leschtinou. EU čeká s rozšírením < na svatého Dyndy> míněni odjinud Süddeutsche Zeitung o rozšiřování SYN2006PUB.

Semantički identičan supstantivni frazem nastao na isti način zabilježen je i u hrvatskom: na svetoga nikada. ${ }^{12}$ Prema HNK frazem ima nultu frekvenciju, što ukazuje na njegovu marginalnu uporabu, ali Google dokazuje njegovu pojavnost.

Npr. kada cete tako opsezan interwiw objavit sa drugom stranom ??? < na svetoga nikada > jelda? G.

a srbi ce svoje optuzenike izruciti < na svetog nikada > ... bas krasno.... G.

Osim prijedloga frazem sadrži i poimeničeni prilog nikad upotrijebljen u kolokaciji s pridjevom sveti, što omogućava da ovaj prilog značenjski bude shvaćen kao vlastito ime. Važno je primijetiti pisanje malog slova kod poimeničenog priloga nikad umjesto velikog što bi bilo primjerenije [usp. FI, 56]. Očito kolebanje pravopisne norme ilustrira primjer:

Npr. E, znaš, kad ću da poslušam sad meteorologe? < Na Svetog Nikada! > G.

2.2.3. Jedina fiktivna svetica koja se pojavljuje u našem materjalu je Dala. ${ }^{13}$ Pripada trećoj skupini frazema u kojoj je fiktivno vlastito ime tvoreno na osnovi igre riječima. Poredbeni frazem tvářit se jako svatá Dala jedinstven je iz nekoliko razloga. To je jedini frazem iz analizirane skupine u kojemu je fiktivna vlastita imenica izvedena od glagola, i to sa semantičkom podlogom glagola dáti. Idiomatičnost je tu najizraženija, kao i sastavnica humora. Ujedno je to i jedini frazem u analiziranom korpusu koji se odnosi na žensku osobu i na negativnu kategorizaciju njenog smetenog, zbunjenog i pomalo glupog ponašanja“.

Npr. Anebo... A zase Lucie. Socha Svobody! A < svatá Dala > !yšly na chodník a ještě se zakuckávaly smíchem SYN2005.

Iveta Blanarovičová, která se obzvlášt’ v upoutávkách na koncert pro nadaci, jižz je patronkou, tvářila jak svatá Dala. „No vidiš, a je to pěkná sviňka, “ dodala Rychtářka G.

Kolokacija pridjeva sveti s fiktivnim vlastitim imenom funkcionira kao antifraza. ČNK naznačuje češće korištenje šire varijante tvářit se j. svatá Dala (a nevěděla komu) (s frekvencijom 3), koja naglašava ironičan stav govornika i često dodaje humoristično erotsko značenje.

Npr. jako študent ve vdově. Anebo i tváři se jako < svatá Dala > (a nevěděla komu). Z oblasti vznešenějši SYN2006PUB.

hlavou vopravdickou svatozár̆ a tváři se jako < svatá Dala > nevéděla komu... To už nemluvím o chlápkovi SYN2006PUB.

Znakovito je da se kod fiktivnih imena pojavljuju kolokacijski ograničeni leksemi, koji su sastavni dio male, ali ipak značajne skupine leksema.

12 Prema frekvenciji (115) na internetu frazem se češće koristi s komponentom fiktivnog praznika: na sveto nigdarjevo u odnosu prema na svetog(a) nikada. Primjeri potvrđuju identično neusuglašenu pravopisnu normu kod poimeničene komponente nigdarjevo kao i kod nikad, što bi vrijedilo razmotriti u jednoj zasebnoj i detaljnijoj studiji. Također je samo ograničeno poznata varijanta na/do svetoga Živ$k a$ koja nije zabilježena u rječniku.

13 L. Stěpanova (usp. SČRF) još navodi: na svatou Trdlici; mit svatou Lenoru. Ovdje ih ne analiziramo jer nismo našli njihovu potvrdu u ČNK i nisu zabilježeni u SČFI. 
Frazemi s fiktivnim vlastitim imenom konceptualno izražavaju stav govornika prema drugom čovjeku te istovremeno opisuju ljudske osobine i način ponašanja (začuđeno Dala, priglupo - Utřinos) ili negativan odnos prema realizaciji (Dyndy, nikad).

\section{Zaključak}

Na temelju navedenog proizlazi da je u oba jezika znakovita pripadnost ovih frazema kolokvijalnom stilu i njihova izrazita ekspresivnost.

Prema frekvenciji ovi se frazemi ponašaju kao marginalne pojave, ali unatoč tome vidljive su razlike između dvaju jezika.

U suodnosu korištenja muških i ženskih vlastitih imena očigledan je veliki nesklad. U promatranom materijalu u oba jezika je naglašena androgena tendencija. Iako je omjer zastupljenosti ženskih vlastitih imenica u hrvatskom jeziku veći ((27\%: 19\%), ni jedno se žensko ime ne pojavljuje u ovdje predstavljenim skupinama frazema, dok je u češkom zabilježeno jedno fiktivno ime.

Frazemi s konkretnim denotatom imaju višu frekvenciju u češkom nego u hrvatskom. Iako se upotrijebljeno vlastito ime vezuje uz konkretnoga sveca, značenje frazema nikada se ne odnosi na njegovu bit. Iz toga proizlazi da u antroponimskim frazemima češkoga $i$ hrvatskoga podrijetla s vlastitim imenom kao sastavnicom u kolokaciji s pridjevom sveti dolazi do dekonkretizacije i desemantizacije sastavnica, što je razlog pojavi da se asocijacija s izvornim značenjem brzo briše.

Ukratko, u hrvatskom jeziku nije toliko česta uporaba fiktivnih imena svetaca (imamo jedno i to dosta marginalno) kao u češkom, gdje se većinom javljaju u neverbalnim i poredbenim frazemima. U ovim frazemima dolazi do spajanja dvaju ekstrema, odnosno kombinacije riječi s manjom i većom ograničenošću u kolokacijama. Očita aluzija na prividno postojeće svece daje im veliku idiomatičnost, šaljivost $i$ apsurdnost, čime je naglašeno vrednovanje pri njihovoj upotrebi.

Frazemi su i odraz sociokulturne sredine koja snažno vrednuje određene pojave. Koriste se s ciljem da kritiziraju, pa zato govornik često izabire naizgled pozitivne sastavnice kao sredstvo za ismijavanje. U oba se jezika negativno vrednuje ili čovjek koji se sa stajališta govornika ponaša moralno ili etički neprimjereno, ili njegov odnos prema poslu, ili prema ostvarivanju čega, ili prema samom sebi.

Veoma niska zastupljenost imena fiktivnih svetaca u hrvatskim frazemima ukazuje na to da njihova uporaba nije univerzalna kategorija za sve jezike (usp. njihovo nepostojanje npr. u ruskom ili makedonskom), nego je kulturno specifična za svaki narod. Razumijevanje ovih frazema, posebno onih s fiktivnim vlastitim imenom kao sastavnicom, usko je povezano sa shvaćanjem humora u jeziku i često se izravno veže s dosta visokim i specifičnim poznavanjem kulture.

Stvaranje fiktivnoga imena nije ograničeno samo na vlastite imenice u svezi s pridjevom sveti (usp. hipotetske praznike hrv. na sveto Nigdarjevo, mak. на Куковден ili toponim: pán z Nemanic itd.), pa bi možda detaljnija analiza ove pojave i njeno uvrštavanje u europski kulturni kontekst dalo drugačije rezultate. 